\title{
IS ENTREPRENEURSHIP INHERITED? A STUDY OF INTERGENERATIONAL SOCIAL MOBILITY IN MEXICO*
}

\author{
Viviana Velez-Grajales ${ }^{* *}$ \\ ROBERTO Velez-Grajales ${ }^{* * *}$
}

\begin{abstract}
The 2006 ESRU Survey on Social Mobility in Mexico is used to identify determinants of the decision to become an entrepreneur and analyze entrepreneurs' intergenerational (i.e., respondents-parents) household wealth mobility. Entrepreneurs are distinguished from own-account workers. First, we find that entrepreneurship is strongly determined by the father being an entrepreneur and not necessarily by the individual's initial wealth or educational attainment. Second, the mean effect of entrepreneurial activity on individual income is positive and greater for those whose parents belonged to the extreme ends of the socioeconomic distribution. Third, it is more likely for entrepreneurs to experience greater upward wealth mobility than non-entrepreneurs.
\end{abstract}

JEL classification: C21, J62, L26

Keywords: social mobility, entrepreneurship, propensity score matching, Mexico

\section{INTRODUCTION}

Equality of opportunity ensures that a person's position in society is the result of a merit-based, competitive process rather than being determined by their socioeconomic origin or the socioeconomic status of their parents. ${ }^{1}$ Velez-Grajales et al. (2011)argue that a good indicator for performance of redistributive policies is that individuals' life achievements depend less on their physical or socioeconomic characteristics and more

\footnotetext{
* This research project was supported by the Inter-American Development Bank (IDB) and the Espinosa Yglesias Research Center. This paper was undertaken as part of the IDB Research Department project "Strengthening Mobility and Entrepreneurship: A Case for The Middle Classes." We thank Aniel Altamirano for his research assistance. Very special thanks are due to Eduardo Lora and Francesca Castellani for sharing their expertise during the whole process of the project. We also want to thank the anonymous reviewers for their comments and recommendations. All remaining errors are our own.

** Inter-American Development Bank, Labor Markets and Social Security Unit, 1300 New York Avenue, N.W. Washington, D.C. 20577, USA. Tel: (202) 623-3686. Email: vivianav@iadb.org, viviana.velez7@ gmail.com.

*** Centro de Estudios Espinosa Yglesias, Av. de las Flores 64-A, Col. Tlacopac, México D.F., 01040. Tel: +52-55-56608031 ext. 106. Fax: +52-55-56608031 ext. 110. Email: rvelezg@ceey.org.mx.

1. Following the capabilities approach proposed by Sen $(1985,1987)$, equality of opportunity should be measured in terms of effective freedom, i.e., available options to choose. It must be noted, however, that equality of opportunity does not assure equality of results (UNDP, 2010).
} 
on their talent and effort. The degree of social mobility, i.e., changes in an individual's social stratum, is an important indicator of a society's success because it is a sign of equal opportunity among children of families with different socioeconomic status.

According to Serrano and Torche (2010), social mobility should be fostered for three main reasons: justice, efficiency, and social cohesion. In regard to justice, a normative reason, it is argued that individuals should earn what they deserve, as in a meritocracy. The argument for efficiency is that a lack of social mobility creates barriers to an optimal allocation of human resources. Finally, the argument related to social cohesion is that social mobility reduces the probability of social conflict.

Some authors argue that there is a negative correlation between inequality and mobility (Erickson and Goldthorpe, 1992; Jantti et al., 2006; Solon, 2004; and Corak, 2013). Empirical evidence confirms this relationship. Latin America, for example, which historically has had one of the highest levels of social inequality in the world, is characterized by persistent intergenerational inequality in a context of low mobility (UNDP, 2010), i.e., the status quo persists across generations. ${ }^{2}$ For instance, Mexico has experienced high levels of household income inequality. As Szekely (2005) shows, during the mid-1980s Mexico's Gini coefficient reached its lowest level: $0.43 .^{3}$ In 2010, the Gini coefficient for Mexico was 0.51ten decimal points higher than the Gini coefficient of the country with the highest coefficient in a sample of industrialized countries (UNDP, 2010). ${ }^{4}$ In terms of social mobility, Mexico has not performed well. Torche (2010) finds that intergenerational social mobility is low and significantly lower at the extreme ends of the socioeconomic distribution. ${ }^{5}$ In this scenario, it is necessary to identify first the barriers for social

2. Deininger and Squire (1996) report that Latin America and the Caribbean have been the regions with the highest Gini coefficients since the $1960 \mathrm{~s}$, with an overall decadal average of 0.50 . In comparison, countries classified as industrial and high-income show a decadal average of 0.34 .

3. It should be noted, however, that during the period Szekely studied (1950-2004), the Gini coefficient was consistently closer to 0.5 than 0.4 . Szekely has estimated income Gini coefficients for several years during the period 1950-2004. In 1950, the coefficient was of 0.52 and it wasn't until 1977 that it dropped below 0.5. In a previous study, Altimir (1987) argues that income is underestimated in household surveys. After adjustments, he reports that Mexico's Gini coefficient is 0.606 for 1963, (0.53 unadjusted) and 0.518 for 1977 (0.482 unadjusted).

4. The sample includes 22 members of the Organization for Economic Co-operation and Development (OECD).

5. Torche estimates a multidimensional intergenerational well-being index using data from the Mexican Social Mobility Survey 2006. According to the results, around 50\% of male household heads (HH) in Mexico with parents who belonged to the lowest quintile stayed within the same quintile, while just $4 \%$ of those $\mathrm{HH}$ reached the top quintile. On the other hand, no $\mathrm{HH}$ with parents in the top quintile fell to the lowest one. 
mobility, and second, the vehicles that may make it possible to break this vicious intergenerational circle.

This study focuses on the latter. Specifically, it analyzes the role played by entrepreneurship in promoting social mobility in Mexico. Whether a person becomes an entrepreneur may depend not only on individual characteristics such as talent or effort, but also on factors such as family wealth or membership in a family of entrepreneurs.

There is little consensus about what constitutes entrepreneurship. Scholars have proposed various definitions which largely depend on the research questions they seek to answer. Early works concerned with defining entrepreneurship can be classified into two thematic groups, the first of which looks at the functions of entrepreneurs in the economy. These include managing uncertainties of the market, innovating, taking risks, and coordinating factors of production. The second focuses on the characteristics of entrepreneurs as individuals. It has been claimed, mainly by behavioral scientists, that entrepreneurs possess special traits such as leadership. It has also been recognized that entrepreneurial characteristics tend to run in families.

Many empirical studies in developed countries equate entrepreneurship with self-employment. According to Parker (2004), "The self-employed are often taken to be individuals who earn no wage or salary but who derive their income by exercising their profession or business on their own account and at their own risk. Likewise, partners of an unincorporated business are usually classified as self-employed. It is sometimes helpful to partition the self-employed into employers and own-account workers (the latter of which work alone), or into owners of incorporated or unincorporated businesses." In this study, we consider entrepreneurs to be individuals who own a business or are partners in a business and employ workers. Own-account workers are considered to be self-employed.

We propose that entrepreneurship is an effective vehicle for upward intergenerational social mobility in Mexico. To test this, first we investigate what determines individuals' occupational choices and how those choices affect their income. Then we examine to what extent entrepreneurs experience greater upward social mobility than the self-employed and employees across generations. For the analysis, data are taken from the 2006 ESRU Survey on Social Mobility in Mexico (EMOVI-2006). This survey collects respondents' current socioeconomic information and the comparable retrospective data on their parents. The analysis is conducted for two birth cohorts of male respondents: 1942-1964 and 1965-1981. 
We find that an individual's decision to become an entrepreneur is strongly determined by the father's occupation and is not necessarily related to the individual's initial wealth or educational attainment. Second, the mean effect of entrepreneurial activity on income is positive in general and relatively larger for those respondents whose parents belonged to the extreme ends of the socioeconomic distribution. Finally, entrepreneurial activity increases an individual's chances for upward mobility across generations. The magnitude of the increase in entrepreneurs' mobility, however, varies with their individual characteristics and family background. Results suggest that although entrepreneurs with lower-income parents experience upward mobility, it is more difficult for them to reach the top end of the socioeconomic distribution compared to those with parents who belong to the middleor high-income segments of the socioeconomic distribution.

The document is organized as follows. In Section 2 we present the definition of a Mexican entrepreneur, while Section 3 describes the data. In Section 4, the determinants of the decision of becoming an entrepreneur are studied. Section 5 provides estimates of the effects of entrepreneurial activity on income and in Section 6 , the intergenerational social mobility of entrepreneurs is analyzed. Section 7 concludes.

\section{ENTREPRENEURSHIP IN MeXico}

In the literature, the concept of entrepreneur is often used without a concise definition; nevertheless, it is usually linked to early theories of entrepreneurship. Richard Cantillon introduced the concept in 1755 , pointing out that entrepreneurs are important to the economy because they are willing to take risks by buying products at known prices without the certainty that they will be able to sell them at a higher price. An entrepreneur brings equilibrium to a market by correctly predicting demand for products. Nearly a century later, Jean-Baptiste Say described entrepreneurs as organizers of factors of production who shift economic resources out of areas of lower productivity into areas of higher productivity and greater yield. Personal characteristics such as judgment, perseverance, and experience help successful entrepreneurs spot business opportunities and generate added value. By the middle of the 20th century, Josef Schumpeter defined entrepreneurs as innovators who introduce "new combinations of means of production." Entrepreneurial innovation results in new products and production processes that promote economic development 
but also destroy old markets - the process of "creative destruction" (Glancey and McQuaid, 2000; Parker, 2004 and Iversen et al., 2008). More recent studies in empirical economics have attempted to model the decision to become an entrepreneur or study the entrepreneurial phenomenon as an evolutionary process to understand how firms change over time (Landstrom et al., 2012).

Who are the entrepreneurs in Mexico? The data from the Mexican national occupation and employment survey (Encuesta Nacional de Ocupación y Empleo, ENOE) indicates that employees account for about two-thirds of workers; roughly one-fourth are own-account workers ${ }^{6}$; around $5 \%$ are owners of or partners in a business with at least one employee and the rest are unpaid workers. According to the Mexican economic census, except for firms in the agriculture sector, there was a total of 3,724,009 private enterprises (including public utilities) in 2008 and 224,002 public enterprises and religious associations. ${ }^{7}$ In terms of firm size, firms with up to two workers constitute $65 \%$ percent of the total while $89 \%$ of firms have five workers or fewer (Lecuona Valenzuela, 2009).

In 2008, the first group of firms generated about 20.1 million jobs while the second one generated about 4.8 million jobs. These workers, added to the 6.3 million who work in the agricultural sector, total approximately 31 million. However, according to the ENOE, the actual number of Mexican workers was around 45 million in 2008. This difference may be due to the fact that ENOE includes all economic activities while the economic census collects data only for enterprises operating from fixed or semi-fixed premises. Economic activities carried out in the streets or in temporary facilities (such as food trucks that are set up and dismantled daily) or the home are excluded. Most of those activities are performed by own-account workers.

We refer to own-account workers as the self-employed. As Levy (2008) describes, self-employment covers a broad range of occupations:

"Self-employed workers can be employed in rural areas (agricultural producers) or in urban areas (fruit juice vendors on city streets). They may or may not own a productive asset, such as land in the case of

6. Levy (2008) considers two types of own-account workers: the self-employed and comisionistas, although the latter are often classified as the former. The earnings of comisionistas are from commissions they receive for selling the products of larger firms, while the self-employed have no contractual relationship with anyone.

7. The census gathers basic economic information on 962 of the 1,049 activity types listed by the North American Industry Classification System (NAICS) (all other activities are covered by the agriculture census). 
a farmer or a blender and a stand in the case of a fruit juice vendor. Workers who make handicrafts (artesanos) with a few simple tools (a drill, a hammer, and some paints) also fall into this category, as do those who shine shoes using shoe polish, a brush, and a box; seamstresses and tailors who use a swing machine to make clothes at home for sale in a tianguis ("market" in Nahuatl); and gardeners who go from one home to another with their lawnmower and hedge trimmer...Lawyers, doctors, accountants, and others who work independently also are self-employed workers...Individuals who wash and park cars on the street also are self-employed. One might think that they own no productive assets, but they may own or have access to intangible capital in the form of special or exclusive rights to the street where they perform their tasks."

Based on early theories of entrepreneurship, we are of the opinion that business owners are a better proxy for entrepreneurs than the selfemployed. First, having employees suggests that business owners saw an opportunity for growth, which is compatible with Say's definition of the entrepreneur. Second, the self-employed may or may not own a productive asset and many of them work at home. Thus it is more likely that business owners have had to take on risk to go into business than own-account workers. That is, individuals who own a business are probably closer to Cantillon's entrepreneur. Third, although innovation is not a question of size, it is more likely that larger firms have enough resources to implement the innovative actions capable of causing market changes, the main characteristic of Schumpeter's entrepreneur.

In this paper, we investigate whether the determinants of becoming an entrepreneur are different from those of the self-employed.

\section{DATA DESCRIPTION}

The 2006 ESRU Survey on Social Mobility in Mexico (EMOVI-2006) was conducted by ESRU Foundation and the Espinosa Yglesias Research Center (Centro de Estudios Espinosa Yglesias, CEEY). ${ }^{8}$ This household survey collects current respondents' socioeconomic information and the comparable retrospective information on their parents. EMOVI-2006 sample is representative for men between 25

8. A second survey, the EMOVI-2011, has already been conducted by the same institution. The sample of that survey is representative of men and women (both household heads and non-household heads) aged 25-64. This new cross-section survey contains retrospective questions on both fathers and mothers as well as more detailed information on respondents' siblings. 
and 64 years old. ${ }^{9}$ Although women were interviewed when no men lived in the household, this study uses the data about male respondents only. A total of 6,322 men completed the interview. The most relevant information collected for the purposes of the study concerns the education and employment information for the respondent and his father. The respondent is asked about the characteristics of his current job and his first job and about his father's job when the respondent was 14 years old. The survey also contains information on the characteristics of the respondent's household and the household of his father.

On average, the men in the sample are 42 years old with a standard deviation of 11 years. More than $90 \%$ of them are heads of household, $6 \%$ are the son of the head of household, and the rest are deemed other relatives. On average, they have completed eight grades of schooling, which corresponds to the second year of junior high school, and $77 \%$ completed primary school. More than $2 \%$ report being unemployed and more than $3 \%$ report that they are retired. Those with a job are distributed in the following sectors of the economy: services (20\%), industry (19\%), trade (18\%), agriculture (12\%), other services such as automotive services, domestic repairs, etc. (12\%), construction (11\%), and transport $(8 \%){ }^{10}$

Almost $60 \%$ of the men are employees in the private or public sector; $8.3 \%$ are owners of or partners in the firm where they work; and $30 \%$ are self-employed. The rest do not report their occupation. Figure 1 shows the occupational distribution of male workers between 24 and 65 years old in Mexico. Since 2005, the proportion of entrepreneurs has fluctuated between 6 and $8 \%$, while the proportion of self-employed has fluctuated between 20 and $27 \%$. It may be the case that our percentage of employers is slightly higher than the one obtained by the ENOE because the sample for our analysis contains a higher proportion of heads of household.

9. The EMOVI-2006 is a nationally representative, fully probabilistic, stratified, multistage survey. The primary sampling units are basic geographic areas for the largest metropolitan areas of the country, i.e., Mexico City, Guadalajara, and Monterrey, and municipalities in the rest of the country. To ensure the sample's geographic and socioeconomic representativeness, the primary sampling units were stratified by number of inhabitants and socioeconomic status. The socioeconomic stratification was done according to an index calculated in terms of the inhabitants' education level, their earnings, and the proportion of households with a sewage system. The secondary sampling units are blocks. For each block, five households were randomly selected. In each household, one respondent was randomly selected.

10. Services include scientific and technical services, government and international organizations, educational services, temporary housing services and preparation of food and beverages, health and welfare services, real estate and rental services, and financial and insurance services. 
The percentage of employers in Figure 1 is consistent with what the Global Entrepreneurship Monitor (GEM) reports as entrepreneurs who have been in business for more than three months. ${ }^{11}$ According to GEM's 2012 survey, in Mexico 7.9\% of adults intend to start a business (potential entrepreneurs), $4.3 \%$ are new business owners (entrepreneurs who have been in business less than 3.5 years), and $4.7 \%$ own an established firm (more than 3.5 years in business). These figures for Latin America overall are 11, 7, and 8\% respectively (Naranjo et al., 2012).

\section{Figure 1. Occupations of men ages 25-64}

\section{(in percent)}

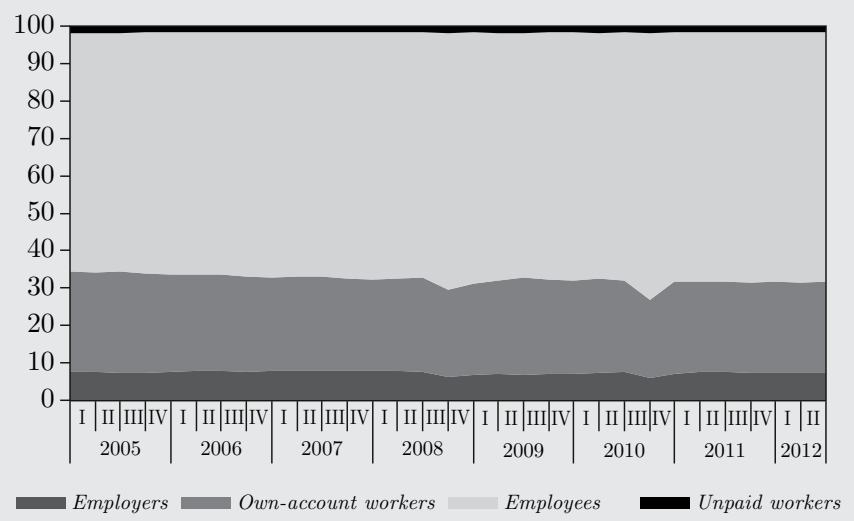

Source: Authors' calculations based on data from the Encuesta Nacional de Ocupación y Empleo 2005-2012

On average, the monthly household income of respondents is 5,390 Mexican pesos, or US $\$ 677$, in 2005 purchasing power parity (PPP). ${ }^{12}$ As expected, compared to the whole sample, the mean monthly household income is higher for entrepreneurs: 7,300 Mexican pesos, or US\$917, 2005-PPP. From this simple income difference we are unable

11. GEM defines entrepreneurship as "any attempt at new business or new venture creation, such as self-employment, a new business organization, or the expansion of an existing business, by an individual, a team of individuals, or an established business." In 2012, GEM administered a survey to a minimum of 2,000 adults (18-64 years old) in each of 69 countries to collect information on the entrepreneurial attitudes, activities, and aspirations of respondents.

12. The purchasing power parity (PPP) factor in 2005 was 7.64 . From the World Development Indicators at http://data.worldbank.org/indicator/PA.NUS.PRVT.PP (12/29/2011). 
to conclude that occupational choice is the reason why entrepreneurs earn more than non-entrepreneurs, because other factors may be necessary for entrepreneurs to be successful, such as family contacts or more grades of schooling. In this article, we compare entrepreneurs to a group of non-entrepreneurs who are comparable in terms of observable characteristics.

\section{INITIAL CONDITIONS AND ENTREPRENEURSHIP RELATIONSHIP}

Several empirical studies on occupational relationships across generations have found that parental entrepreneurship is a strong determinant of entrepreneurship. Most of these studies use data from developed countries. Dunn and Holtz-Eakin (2000) use data from the National Longitudinal Survey to investigate the relative importance of parental wealth and self-employment experience and individual's own wealth and human capital on the probability of transitioning from a salaried job to self-employment. They conclude that "parental self-employment has a strikingly large and statistically significant effect on the propensity to become self-employed. This influence emerges even after controlling for the positive influence of access to capital through the individual and/or his parents, as well as the son's general human capital." More recent studies further investigate the types of advantages, skills, and resources passed on from parents to children that influence occupational status (Corak and Piraino (2011); Wyrwich (2013)).

We investigate the factors that may be important for becoming an entrepreneur in Mexico, using probit equations to estimate the probability of being an entrepreneur. We attempt to establish causality by using pre-determined variables as independent variables, which are grouped into four categories. First, the sociodemographic variables include respondents' age, completed grades of schooling (a proxy for human capital), whether they are of indigenous origin, and whether they were raised in a rural or urban area. Second is the size of the enterprise they worked for in their first job, which is expected to capture the effect of family ties or attitudes towards entrepreneurship on the probability of becoming a business owner. As our estimates show below and as might be expected, the probability of becoming an entrepreneur increases when individuals start their work history in a microenterprise, which could reflect that entrepreneurs are willing to engage in new ventures. This probability also increases when the 
respondent's first job is in a large enterprise, which may mean that potential entrepreneurs understand how to take advantage of networks and other external relationships. Third, parents' socioeconomic class is expected to capture the importance of initial capital constraints for entrepreneurial activity (socioeconomic classes are defined according to the wealth indices estimated in Section 6). Fourth is father's occupation, which aims to capture the effect that parental transmission of personal traits and entrepreneurship education has on occupational choice.

Concerning the effect of initial capital constraints on the propensity to become an entrepreneur, there is a large body of literature that shows a positive relationship between initial household wealth and entrepreneurship in industrialized countries. This has been interpreted as evidence of liquidity and/or credit constraints for entrepreneurship (see discussions in Quadrini, 1999 and Hurst and Lusardi, 2004). In Mexico, Lecuona Valenzuela (2009) claims that although from 2004 to 2008 the total number of firms in the country increased by 24 percentfrom 3.24 to 3.72 million - from 2000 to 2007 the share of available financial resources allocated to entrepreneurial activities decreased from 30 to $23 \%$. Credit constraint is one of the main reasons that entrepreneurs do not take advantage of opportunities for economies of scale to increase the added value of their activity. The author claims that even though $42 \%$ of commercial banks' credit portfolios in 2007 were allocated to entrepreneurial activities, on average only $11 \%(0.7 \%$ of GDP) of these portfolios was available for smaller clients; almost $80 \%$ was concentrated on the 300 largest clients of each bank. Other studies, however, claim that liquidity constraints do not significantly affect the formation of small businesses. Hurst and Lusardi (2004) found that in the United States there is no "discernible relationship" between household wealth and business entry rates for individuals below the $95^{\text {th }}$ percentile. We expect the socioeconomic class of parents to explain, to a certain degree, the ability of some individuals to obtain the capital needed to start a business.

A multi-probit model is used to estimate the probabilities of being an entrepreneur, self-employed or an employee. Table 1 shows the marginal effects for selected variables and indicates which ones affect more or less the propensity to become an entrepreneur when compared to the propensity to become self-employed. ${ }^{13}$ The results support our

13. Multicollinearity issues do not seem to be present. The estimated variance inflation factors are lower than 10 . 
claim that the determinants for becoming an employer are different from those for self-employment. Schooling increases the probability of being an entrepreneur, while having lived in an urban area when young increases the propensity to become an entrepreneur and decreases the probability of being self-employed. Also, entrepreneurs are less likely to have parents who belonged to the low end of the wealth distribution. ${ }^{14}$ Finally, it is interesting to observe that individuals who started working in a microenterprise or as self-employed are more likely to become entrepreneurs. This, together with the fact that employers tend to be older, could mean that sometimes self-employment is the first step in the process of becoming an entrepreneur.

Variables related to the father's occupation are the ones that have the greatest effect on the decision of whether to become an entrepreneur. Having a father who is an entrepreneur increases the probability by 0.14 , versus having a father who is self-employed. Also, having a father who worked in a large firm as opposed to a small or medium-sized enterprise (SME) increases the probability by 0.039 . Unexpectedly, it cannot be concluded that the parents' socioeconomic class affects an individual's decision to become an entrepreneur. Nor does the number of completed grades of schooling have a significant effect on the decision. These results suggest that entrepreneurship in Mexico is strongly determined by the father's occupation and not necessarily by the individual's initial wealth or educational attainment. ${ }^{15}$ Again, it should be noted that the sample under analysis includes only those who are entrepreneurs at the time of the interview, but not all of those who failed at an entrepreneurial activity and ceased to be entrepreneurs. Therefore, it may be that having a father who is an entrepreneur also increases the entrepreneurship survival/success rate.

For the self-employed and employees, the father's occupation is the variable that has the greatest effect on their sons' choice of occupation. In both cases, having a father who is self-employed (employed) increases the probability of becoming self-employed (employee) by around 0.2. Some of the positive determinants of the decision to become an employee are negative ones for the decision to become self-employed. For instance, while having worked in a large enterprise or microenterprise for the

14. The way in which we measure household wealth is explained below.

15. This does not mean that education is not an important determinant of success for entrepreneurs. When returns to school are estimated using a Mincer earnings model, the coefficient of years of education is 0.08 (with a standard error of 0.011 ). 


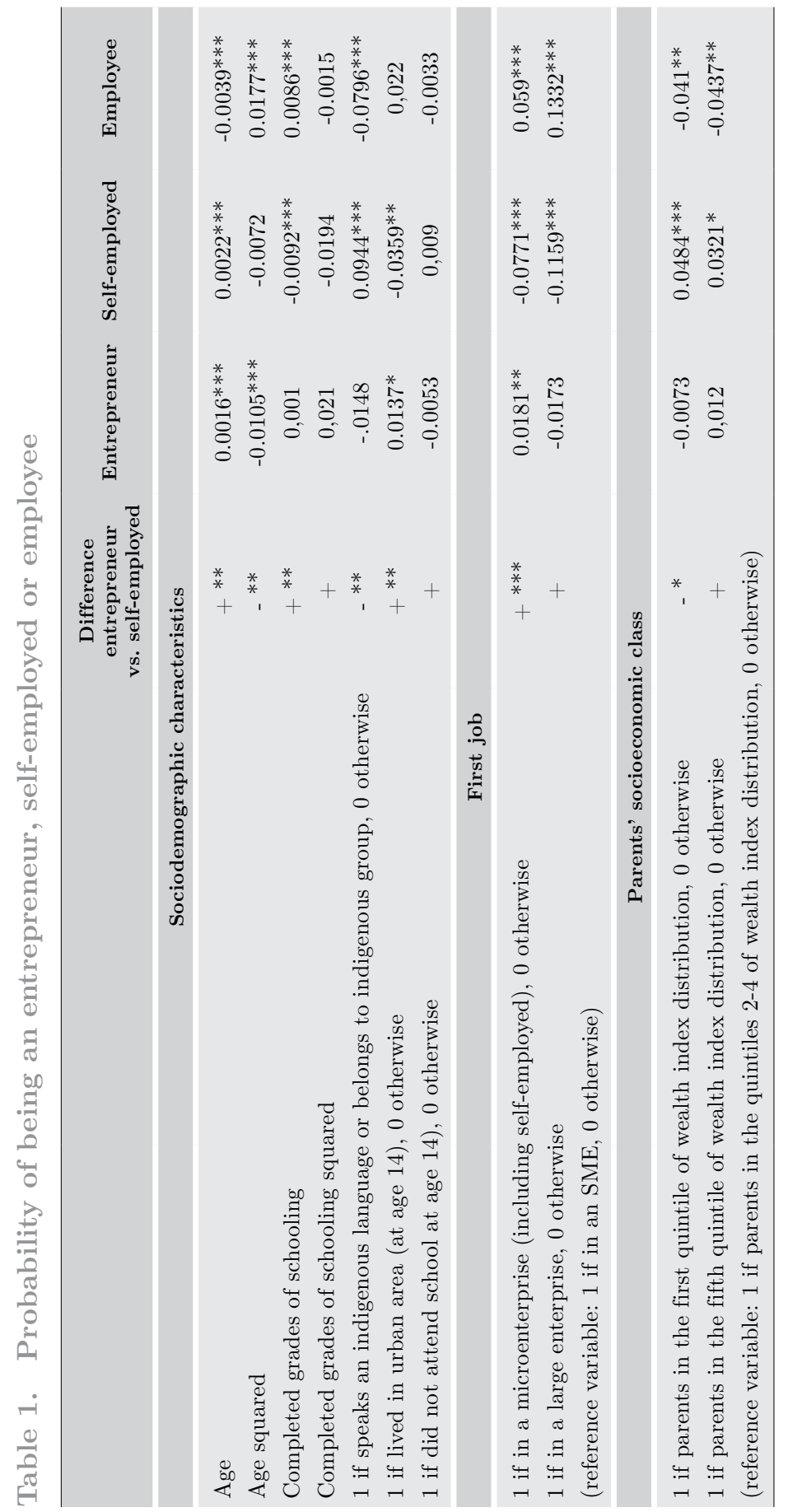




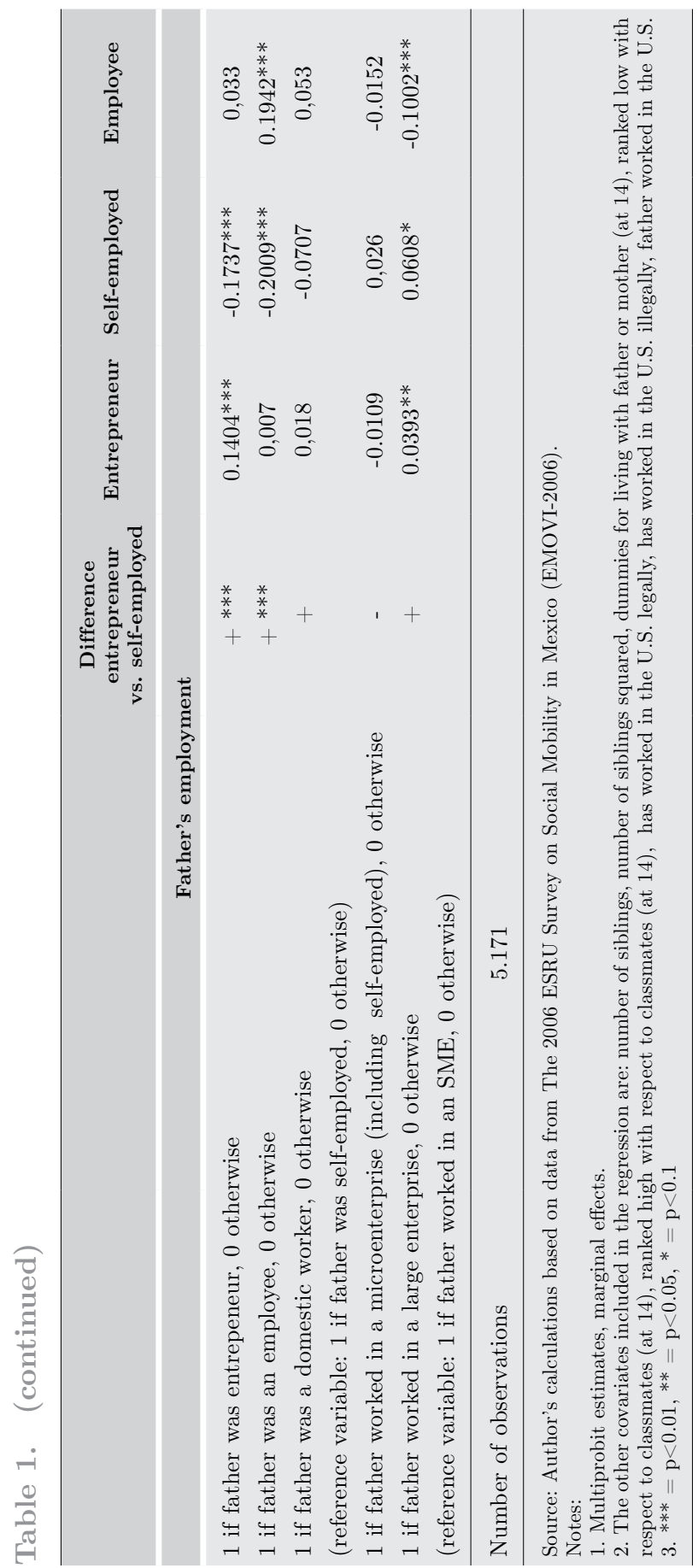


first job increases the probability of being self-employed, it decreases that probability for the employee. Also, speaking an indigenous language or belonging to an indigenous group negatively affects the decision of whether to become an employee, while it has a positive effect on the decision to be self-employed. Having a father who was an entrepreneur decreases the probability of becoming self-employed, but not the probability of becoming an employee. It could be that when a family business is established, next-generation family members have the option of becoming employees of the enterprise or another enterprise within the father's business network.

\section{ENTREPRENEURSHIP AND INCOME}

To measure the effect of entrepreneurship on income, we would have to compare the actual income of entrepreneurs to their potential income had they not chosen to become entrepreneurs. That is, if $Y_{1}$ is an entrepreneur's income and $Y_{0}$ is the income of the same individual had he not become an entrepreneur, the effect on income is $\Delta=Y_{1}-Y_{0}$. Because it is not possible to observe the same individual in both states at the same time, we must estimate their income in the absence of entrepreneurial activity. A method for measuring the impact of social programs is applied to estimate this (Heckman et al., 1997, 1998a, b).

The parameter of interest is known in the evaluation literature as treatment on the treated:

$$
\begin{aligned}
& E(\Delta \mid T=1)=E\left(Y_{1}-Y_{0} \mid X, T=1\right) \\
& =E\left(Y_{1} \mid X, T=1\right)-E\left(Y_{0} \mid X, T=0\right)
\end{aligned}
$$

Where $X$ denotes a set of conditioning variables, $T=1$ if an individual is an entrepreneur (treated), and $T=0$ if an individual is not an entrepreneur (non-treated). The first expectation $E\left(Y_{1} \mid X, T=1\right)$ can be estimated, but the data for the second expectation $E\left(Y_{0} \mid X, T=1\right)$ are missing. Matching estimators are used to impute that expectation.

The idea is to pair each treated individual with an observable, similar, non-treated individual, so that after conditioning on a set of observable characteristics $Z$, the $Y_{0}$ distribution observed for the matched nontreated individuals can be substituted for the missing $Y_{0}$ distribution for treated individuals. The main assumption of matching methods is that the non-treated outcome $Y_{0}$ is independent of treatment 
conditional on $Z$. Therefore, the difference in the mean values of the income outcomes can be attributed to the treatment.

Here, the "treatment" is entrepreneurial activity. The set of observed characteristics used for the matching are those used in the previous section to estimate the probability of becoming an entrepreneur. Matching on many variables could generate the problem that for some combinations of characteristics of treated individuals, no non-treated pairs are available. To reduce the "high dimensionality problem" that arises when $Z$ is large, the propensity score theorem by Rosenbaum and Rubin (1983) is applied. It states that when matching on $Z$ is valid, then matching on the propensity score $\operatorname{Pr}(T=1 \mid Z)$ is also valid. This is the conditional probability of becoming an entrepreneur. The second assumption of the matching method is $0<\operatorname{Pr}(T=1 \mid Z)<1$. This guarantees that for each treated individual we can find a match in the non-treated population. A probit model is used to obtain the propensity scores for entrepreneurs and non-entrepreneurs.

The mean effect of entrepreneurship on income, $\Delta Y$, is calculated using the estimator

$$
\Delta Y=\frac{1}{N} \sum_{i \in N}\left(Y_{i}-\frac{1}{J} \sum_{j \in J} Y_{J}\right)
$$

where $N$ is the number of entrepreneurs and $J$ is the number of propensity score-matched non-entrepreneurs.

The assumption that selectivity in entrepreneurship depends only on observable characteristics is strong. Scholars agree that unmeasurable variables such as ability and family ties are important determinants of occupational choice. We expect first job conditions, parental socioeconomic class and father's occupation to capture those effects. For instance, we assume that entrepreneurial skills are passed on from entrepreneurial fathers to sons. To further minimize selection bias, we choose the closest matches in terms of propensity score by using nearest neighbor instead of kernel estimators.

The effects of being an entrepreneur on individual income are estimated for four groups of individuals: entrepreneurs in general and entrepreneurs with parents from each socio-economic class. Tables 2 and 3 present the estimated impacts. Notice that the simple mean difference in incomes is higher than the estimated propensity score 
Table 2. Estimated effects on individual income for entrepreneurs

\begin{tabular}{|c|c|c|c|c|c|c|c|}
\hline \multirow{2}{*}{ Estimator } & \multicolumn{2}{|c|}{ Mean income } & \multirow{2}{*}{$\begin{array}{c}\text { Effect } \\
\text { (Std. error) }\end{array}$} & \multicolumn{2}{|c|}{ Observations } & \multirow{2}{*}{$\begin{array}{l}\text { Percent } \\
\text { change }\end{array}$} & \multirow{2}{*}{ T-stat } \\
\hline & Entrepr. & Non-entrepr. & & Entrepr. & Non-entrepr. & & \\
\hline Means difference & 5,919 & 4,146 & $\begin{array}{l}1,773 \\
(258)\end{array}$ & 365 & 4,528 & 30 & 6,86 \\
\hline $\begin{array}{l}\text { Nearest neighbor (1) } \\
\text { with replacement }\end{array}$ & 5,819 & 4,980 & $\begin{array}{c}839 \\
(429)\end{array}$ & 362 & 325 & 14 & 1,96 \\
\hline $\begin{array}{l}\text { Nearest neighbor (4) } \\
\text { with replacement }\end{array}$ & 5,819 & 4,793 & $\begin{array}{l}1,026 \\
(367)\end{array}$ & 362 & 1,049 & 18 & 2,8 \\
\hline $\begin{array}{l}\text { Nearest neighbor ( } 7) \\
\text { with replacement }\end{array}$ & 5,819 & 4,980 & $\begin{array}{c}839 \\
(360)\end{array}$ & 362 & 1,606 & 14 & 2,33 \\
\hline $\begin{array}{l}\text { Nearest neighbor (10) } \\
\text { with replacement }\end{array}$ & 5,819 & 5,100 & $\begin{array}{c}718 \\
(355)\end{array}$ & 362 & 2,029 & 12 & 2,02 \\
\hline $\begin{array}{l}\mathrm{NN}(3) \text { with replacement } \\
+ \text { caliper }(0.001)\end{array}$ & 5,770 & 4,503 & $\begin{array}{l}1,267 \\
(428)\end{array}$ & 272 & 584 & 22 & 2,96 \\
\hline $\begin{array}{l}\mathrm{NN}(3) \text { with replacement } \\
+ \text { caliper }(0.002)\end{array}$ & 5,752 & 4,749 & $\begin{array}{l}1,003 \\
(407)\end{array}$ & 311 & 690 & 17 & 2,46 \\
\hline $\begin{array}{l}\mathrm{NN}(3) \text { with replacement } \\
+ \text { caliper }(0.003)\end{array}$ & 5,810 & 4,711 & $\begin{array}{l}1,098 \\
(399)\end{array}$ & 331 & 753 & 19 & 2,75 \\
\hline $\begin{array}{l}\mathrm{NN}(3) \text { with replacement } \\
+ \text { caliper }(0.004)\end{array}$ & 5,811 & 4,733 & $\begin{array}{l}1,078 \\
(393)\end{array}$ & 338 & 777 & 19 & 2,74 \\
\hline $\begin{array}{l}\mathrm{NN}(3) \text { with replacement } \\
+ \text { caliper }(0.008)\end{array}$ & 5,824 & 4,767 & $\begin{array}{l}1,056 \\
(380)\end{array}$ & 353 & 826 & 18 & 2,78 \\
\hline $\begin{array}{l}\mathrm{NN}(3) \text { with replacement } \\
+ \text { caliper }(0.02)\end{array}$ & 5,819 & 4,804 & $\begin{array}{l}1,015 \\
(374)\end{array}$ & 362 & 838 & 17 & 2,71 \\
\hline Radius caliper (0.001) & 5,827 & 4,809 & $\begin{array}{l}1,017 \\
(367)\end{array}$ & 344 & 4,154 & 17 & 2,77 \\
\hline Radius caliper (0.002) & 5,803 & 4,931 & $\begin{array}{c}871 \\
(355)\end{array}$ & 355 & 4,395 & 15 & 2,45 \\
\hline Radius caliper (0.004) & 5,819 & 4,996 & $\begin{array}{c}823 \\
(347)\end{array}$ & 362 & 4,488 & 14 & 2,37 \\
\hline Radius caliper (0.008) & 5,819 & 4,932 & $\begin{array}{c}887 \\
(344)\end{array}$ & 362 & 4,523 & 15 & 2,58 \\
\hline
\end{tabular}

Source: Authors' calculations based on data from The 2006 ESRU Survey on Social Mobility in Mexico (EMOVI-2006).

Notes: Results are presented only for cases where balance is verified.

For the nearest neighbor + caliper estimator, results do not vary much when the number of neighbors changes.

The effect was also estimated using kernel estimators but most often covariates were not balanced.

matching effect for every group of entrepreneurs except for quintile 1. This suggests that, in general, the simple mean difference of individual income between entrepreneurs and non-entrepreneurs overestimates the size of the effects.

Our results suggest that entrepreneurs are more successful than individuals with comparable initial conditions who decide to become self-employed 


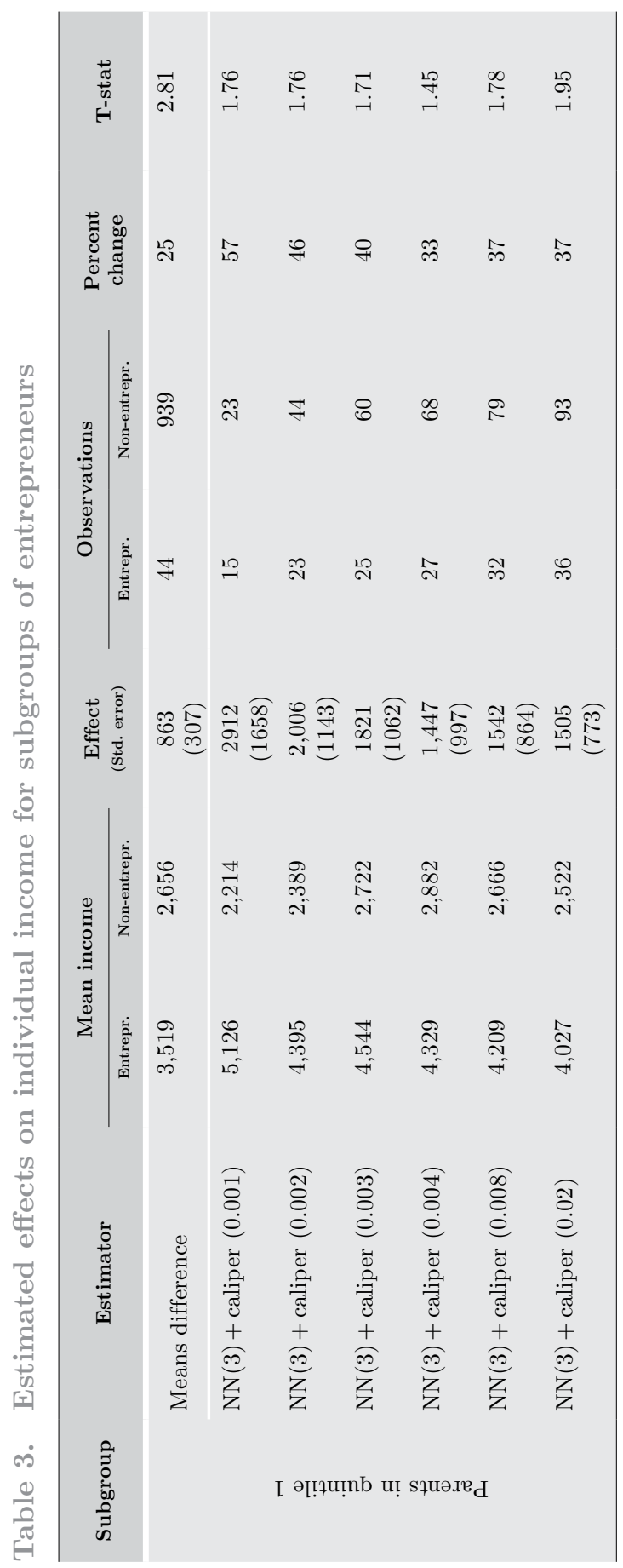




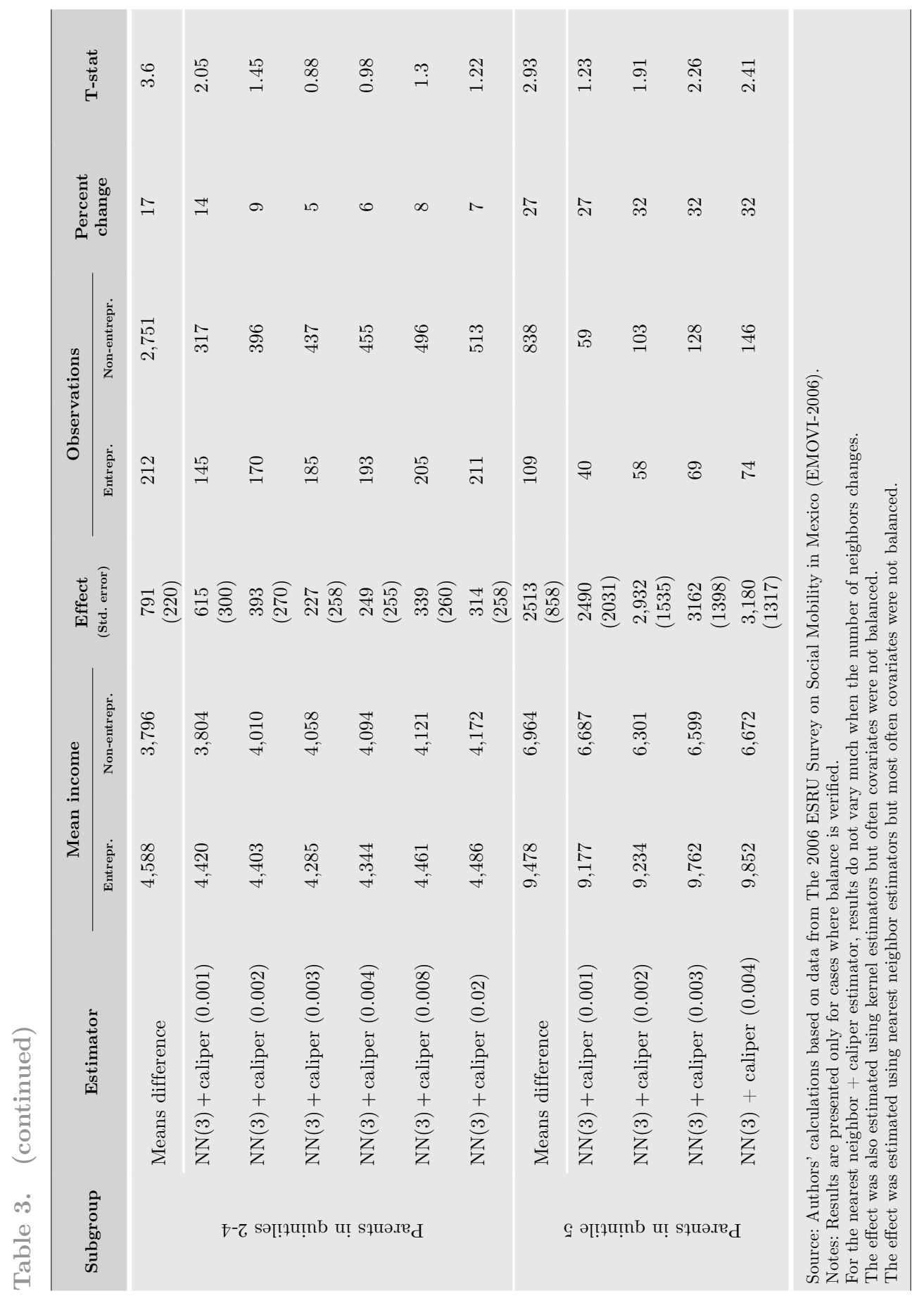


or employees. For the group of all entrepreneurs, entrepreneurship increases income by 12 to $22 \%$. It may be that entrepreneurs learn skills or take advantage of latent traits that enable them to succeed in entrepreneurial life that non-entrepreneurs do not necessarily develop.

The estimates imply that liquidity constraints may be delaying entrepreneurial success. The effect on income is also positive when estimations are performed for entrepreneurs with parents from different socioeconomic classes. The effect observed for entrepreneurs with parents who belonged to the first quintile (33 to 57\%) and the fifth quintile (27 to $32 \%$ ) is higher than that observed for entrepreneurs with middle-class parents (5 to $14 \%$ ). ${ }^{16}$ Based on the assumption that potential entrepreneurs are equally distributed across parental socioeconomic classes, two conclusions can be drawn. On the one hand, the effect on income for those entrepreneurs with parents who belonged to the highest quintile is greater than that for those from quintiles 2-4, suggesting that the success/survival rate decreases with a decrease in barriers to entrepreneurial activities such as lack of credit or limited resources. On the other hand, that the relative effect on income is higher for those with parents who belonged to the lowest quintile suggests that only entrepreneurs engaged in the most profitable activities are able to eliminate entry barriers.

\section{ENTREPRENEURSHIP AND INTERGENERATIONAL MOBILITY}

Social mobility refers to individuals' changes from one social stratum to another. In the literature, social mobility is analyzed in terms of several dimensions. Income mobility measures are the most commonly used (Black and Devereux, 2010). Because human capital accumulation through schooling is considered one of the principal vehicles for ascending the social ladder, completed grades of schooling is another commonly studied dimension. Social class is used as a dimension to measure social mobility in the sociological literature. Torche (2009) argues that this approach captures the value of several market assets such as specific skills, work position, sector of economic activity, education, and

16. To assess the quality of the matching, a statistical test for the difference of population means is performed. This consists of comparing the average values of the covariates used to estimate the probability of being an entrepreneur (propensity score model) between treated and non-treated groups. With p-values greater than 0.05 the null cannot be rejected at $5 \%$. In this case, for every variable, it cannot be rejected that the means are the same after the matching is performed. The results are available from the authors upon request. 
others. The most commonly used classification for social mobility and stratification studies is the Comparative Analysis of Social Mobility in Industrialized Nations (CASMIN), a social class grouping defined by Erikson and Goldthorpe (1992). A fourth dimension of social mobility is wealth. As Torche and Spilerman (2010) argue, wealth can increase consumption in the long term and reduce households' vulnerability. Also, wealthier households are less restricted and can make long-term investments, such as education for children. Social mobility can also be measured through social perception. In this sense, Huerta (2010) affirms that perception is a main determinant of individuals' well-being.

For this study, socioeconomic changes are measured across generations, i.e., changes experienced by individuals in relationship to their parents, or intergenerational mobility. Numerous studies in the literature (Solon, 1992, 2002; Behrman, Gaviria, and Székely, 2001; Mazumder, 2005; Jantti et al., 2006) have focused on this type of analysis. The most frequently studied relationship relates parental earnings to children's earnings (Behrman and Taubman, 1990; Solon, 1992). Because the EMOVI-2006 contains information on income only for the respondents' generation, it is not possible to estimate intergenerational earning elasticities. Therefore, for this study, intergenerational mobility is measured by calculating the intergenerational persistence of household wealth.

To measure wealth, an index of household assets and completed grades of schooling is constructed. As discussed in Sahn and Stifel (2003), using an asset-based index instead of the standard expenditures or income to analyze issues of poverty and inequality has several advantages. The main advantage is that poverty reduction is largely predicted by the individual's ability to accumulate assets. This requires selecting a set of weights to obtain an index of the form:

$$
A_{i}=\gamma_{1} a_{i 1}+\ldots \gamma_{K} a_{i K}
$$

Where $A_{i}$ is the asset index, the $a_{i K}$ 's are the individual assets and the $\gamma$ 's are the weights.

The weights are estimated using the principal components analysis method. Then, correlations between the indices of parents and children are estimated. This is done for the whole sample and also for entrepreneurs, employees, and the self-employed.

The principal component analysis technique is used to reduce the dimension of a set of variables by constructing fewer new variables that 
capture the variation in the original set. The new variables are linear combinations of the original variables. The first principal component is the combination that explains the largest amount of variation. The second principal component is the combination that best explains the remaining variability, and so on. In this investigation, the asset index is the first principal component.

Indices are computed for both the assets of the respondents and those of their parents. Following the notation in Filmer and Pritchett (2001), the formula of the index for each household $A_{j}$ can be written as:

$$
A j=f_{1} \cdot \frac{a_{j i}-a_{1}}{s_{1}}+\cdots+f_{N} \cdot \frac{a_{j N}-a_{N}}{s_{N}}
$$

where $f_{1}$ is the weight in the linear combination for asset $i$; $a_{j i}$ is the value assigned to asset $i$; and, $a_{i}$ and $s_{i}$ are the mean and standard deviation of the $i$-th asset variable over all households.

Three types of household assets are considered: durables, household characteristics, and access to credit. Most of the variables are binary. The value 1 represents ownership or access and 0 is the lack of the asset. Therefore, a change from 0 to 1 for the variable results in a discrete change of $f_{1} / s_{i}$ in the index. Examples of durables are cars, televisions, telephones, and books. Household characteristics include having a toilet, access to hot water, and electricity. Finally, variables associated with credit access include ownership of a bank account and ownership of a credit card. The set of asset variables available in the data is not the same for respondents and parents.

Respondents were born over a period of 39 years, from 1942 to 1981. Because it is probable that the value of assets changed over time, indices are estimated separately for two groups of respondents: those who were born in 1942-1964 and those who were born in 1965$1981^{17}$. Correspondingly, indices for the parents of each group of respondents are estimated. Table 4 shows the weights and marginal effects assigned to the variables that constitute the asset indices for respondents, and Table 5 shows those for their parents. Fathers of the second generation of respondents were born, on average, 18 years later than those of the first generation, which is consistent with the 
difference of 20 years in the average year of birth between the two generations of respondents.

All variables have a positive effect on the indices of both groups. Having domestic service and access to the Internet are the assets that most increase the indices, by more than 0.8 units. The ownership of assets that facilitate access to credit, such as having a credit card or bank account, also increases the index significantly. Examples of variables that raise the index by less than 0.60 units include having access to hot water and owning a telephone, a television, or a car.

As in Filmer and Pritchett (2001), the internal coherence of the asset index is tested by comparing average asset ownership across households with different levels of wealth, in this case by computing the means of asset variables across households of different quintiles of the index distribution. For every variable the proportion of households that own the asset increases with the quintile. For instance, for the first generation of respondents, only $12 \%$ of those in the first quintile and $47 \%$ of households in quintiles $2-4$ own a car, while $91 \%$ of those in the last quintile do so. For some variables the differences are larger than for others. More than $90 \%$ of the households have electricity in each of the three groups. However, while only $11 \%$ of those in the first quintile have access to hot water, $96 \%$ of those in the top quintile have that asset. Comparisons are similar for the second generation of respondents. ${ }^{18}$

In the case of the asset index computed for the parents of respondents, all assets have a positive effect on the index as well. As shown in Table 5 , having domestic service is the asset that increases the index the most for both generations. Variables associated with access to credit, such as having a bank account or having savings, raise the index substantially. The variable that lowers the index the most is ownership of the house in which they live, by 0.03 for the first generation and 0.08 for the second generation.

The asset index for parents of respondents is internally coherent in the sense that the average asset ownership of variables with positive weights increases with the quintile of the index distribution while average asset ownership decreases with negative weights. The only exception is ownership of the home in which the respondent lived when he was 14 years old. A higher percentage of first quintile parents - $76 \%$

18. Tables with these means are available from the authors upon request. 


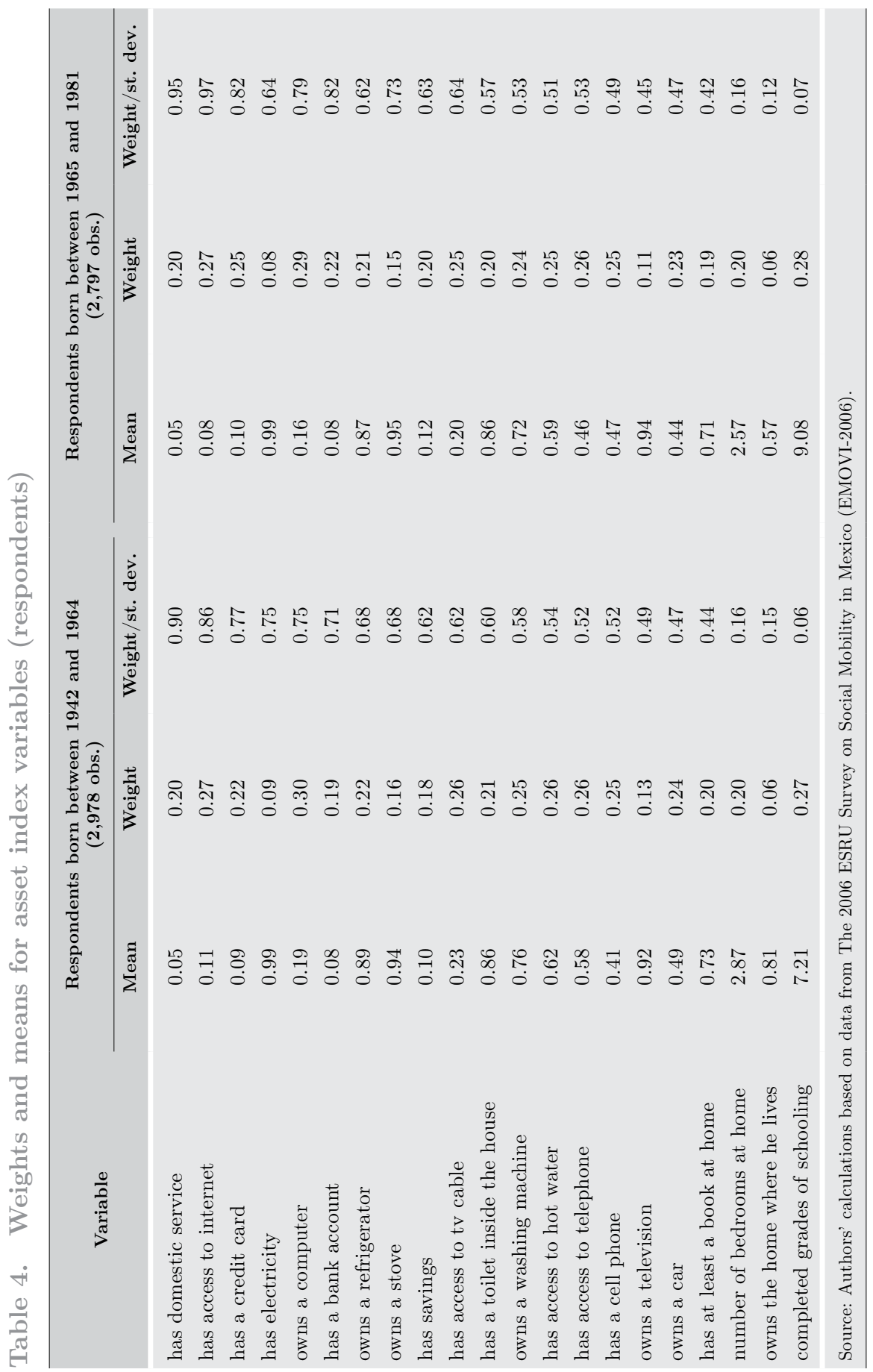




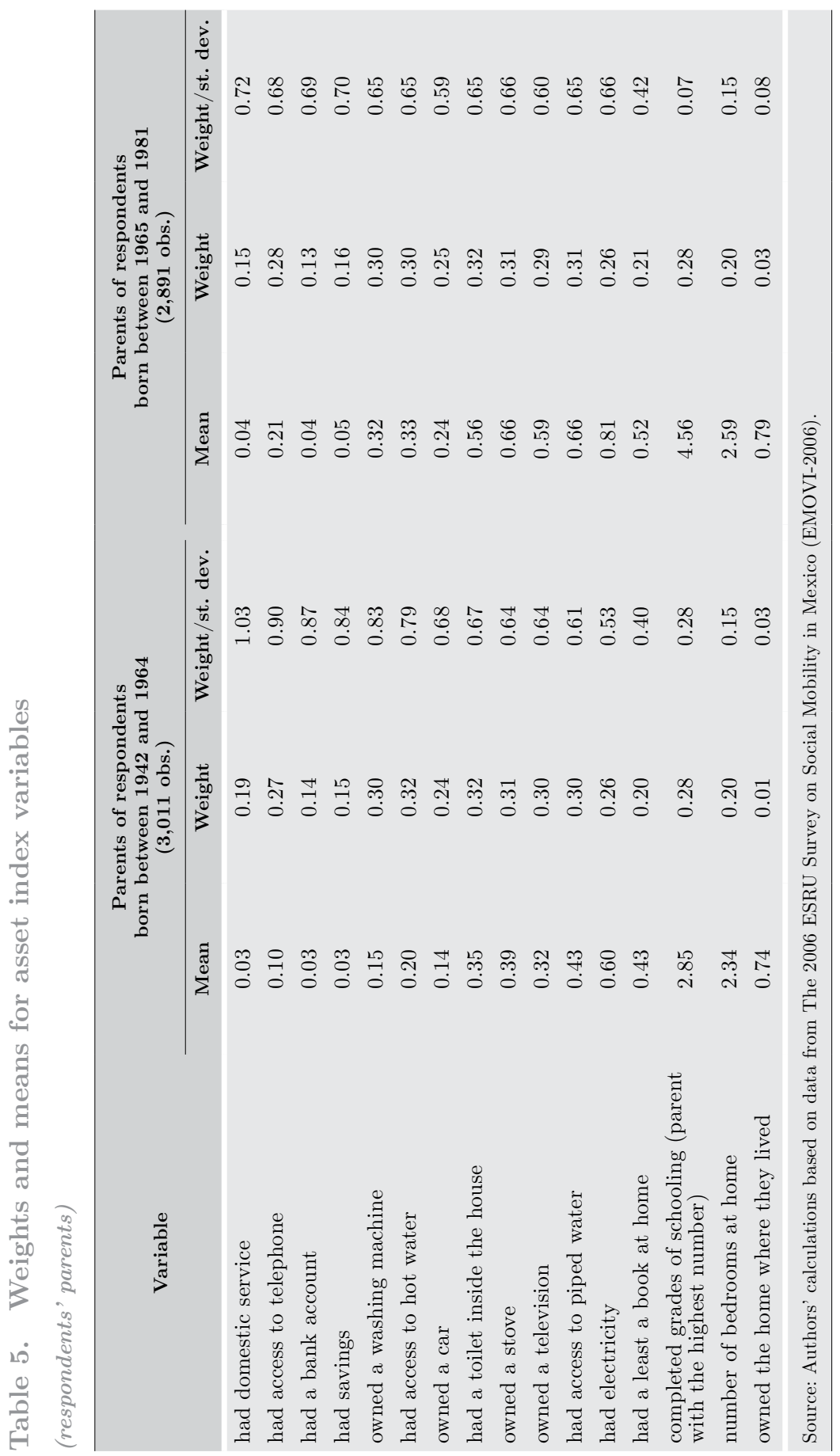


for the first generation and $80 \%$ for the second one- owned the home than parents in quintiles 2-4, where the percentages were 73 and $75 \%$, respectively. It is probable that a higher proportion of parents in quintiles 2-4 rented their homes. As distinct from respondents' households, their parents had more limited access to electricity, particularly those in the lower quintiles. Less than $1 \%$ of parents in the lowest quintile of the first generation had electricity while the figure is $20 \%$ for those of the second generation. These percentages for quintiles 2-4 are 68 and $95 \%$, respectively. ${ }^{19}$

Once the indices are computed, the transition matrix for relative intergenerational mobility is calculated. The matrix shows the proportions of respondents, or children, that experienced upward, downward, or no mobility with respect to their parents. Table 6 presents the transition matrices for the whole sample and the subsample of entrepreneurs for the two previously determined respondent birth cohorts. The numbers in the main diagonal of the matrix, i.e., 47, 69 and $53 \%$ for Matrix 1, show the proportions of children that stay in the same quintile as their parents, or those children who did not experience relative mobility. The numbers below the diagonal refer to those who experienced downward mobility, and the ones above refer to those who experienced upward mobility. For example, in Matrix 1, 4\% of respondents with parents in the lowest quintile moved up to the top quintile of the asset index distribution, and only $2 \%$ of respondents with parents in the top quintile moved down to the lowest quintile.

When comparisons are made between the sub-sample of entrepreneurs and the whole sample, the results show that in general entrepreneurs experience a higher degree of upward mobility and a lower degree of downward mobility. Entrepreneurs born between 1942 and 1964 with parents in the lowest quintile experienced higher mobility, with $64 \%$ moving upwards (61\% to quintiles $2-4$ and $3 \%$ to the top quintile), versus $53 \%$ for the whole sample. This was not the case for those entrepreneurs born between 1965 and 1981, who moved less than the whole sample: more than $42 \%$ moved to quintiles 2-4 and around $3 \%$ moved to the top quintile, while $47 \%$ of the entire sample moved up to quintiles 2-4. For entrepreneurs with parents in the middle quintiles, the proportion of those moving upwards to the top quintile, 
around $30 \%$ for both birth cohorts, is almost double that of the whole sample. The proportion of those moving downward, around $7 \%$ for entrepreneurs born between 1942 and 1964 and 9\% for those born between 1965 and 1981, is about half that of the whole sample, respectively. For entrepreneurs with parents in the top quintile, the proportion of those moving downwards to quintiles $2-4$ is $28 \%$ for the first generation and $22 \%$ for the second one, versus 42 to $45 \%$ for the whole sample. That proportion for entrepreneurs born between 1942 and 1964 moving to the lowest quintile, around $4 \%$, is double that of the whole sample. Entrepreneurs of the other birth cohort moved as much as the whole sample.

In summary, results from the transition matrices suggest two main results: (1) there are more opportunities for upward mobility for entrepreneurs, but, (2) for those with lower-class parents, it is more difficult to reach the top end of the socioeconomic distribution compared to those entrepreneurs with parents who belong to the middle or upper end of the distribution.

\section{Table 6. Transition matrices}

\section{(in percentages)}

\begin{tabular}{|c|c|c|c|c|c|c|c|}
\hline & & \multicolumn{6}{|c|}{ Respondents' wealth index } \\
\hline & & \multicolumn{3}{|c|}{ All } & \multicolumn{3}{|c|}{ Entrepreneurs } \\
\hline & & $\begin{array}{c}\text { Quintile } \\
1\end{array}$ & $\begin{array}{c}\text { Quintiles } \\
2-4\end{array}$ & $\begin{array}{c}\text { Quintile } \\
5\end{array}$ & $\begin{array}{c}\text { Quintile } \\
1\end{array}$ & $\begin{array}{c}\text { Quintiles } \\
2-4\end{array}$ & $\begin{array}{c}\text { Quintile } \\
5\end{array}$ \\
\hline \multirow{6}{*}{ 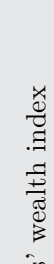 } & & \multicolumn{6}{|c|}{ Respondents born between 1942 and 1964} \\
\hline & & \multicolumn{3}{|c|}{ Matrix 1} & \multicolumn{3}{|c|}{ Matrix 2} \\
\hline & Quintile 1 & 47 & 49 & 4 & 36 & 61 & 3 \\
\hline & Quintiles 2-4 & 17 & 69 & 14 & 7 & 67 & 26 \\
\hline & Quintile 5 & 2 & 45 & 53 & 4 & 28 & 68 \\
\hline & & \multicolumn{6}{|c|}{ Respondents born between 1965 and 1981} \\
\hline$\ddot{ٍ}$ & & \multicolumn{3}{|c|}{ Matrix 3} & \multicolumn{3}{|c|}{ Matrix 4} \\
\hline \multirow[t]{3}{*}{$\sim$} & Quintile 1 & 50 & 47 & 3 & 55 & 42 & 3 \\
\hline & Quintiles 2-4 & 17 & 70 & 13 & 9 & 63 & 28 \\
\hline & Quintile 5 & 2 & 42 & 56 & 2 & 22 & 76 \\
\hline
\end{tabular}


Because the indices are continuous variables we are able to measure intergenerational relative mobility by running regressions of the respondents' asset index on the parents' asset index. Following Behrman et al. (2001), we define the model as:

$$
S_{i, t}=\alpha+\beta S_{i, t-1}+\omega_{i, t}
$$

Where $S_{i, t}$ is the outcome of interest (completed grades of schooling, occupational status constructed as a continuous variable, asset-based index) for individual $i$ from birth cohort $t$ and $\omega$ is a stochastic error independent of the previous generation outcome that is assumed to be independently distributed across individuals and across generations. Estimates of $\beta$ close to one suggest very limited intergenerational mobility, while estimates of $\beta$ close to zero suggest that the outcome is not closely related across generations. Thus, $\beta$ is a measure of intergenerational persistence or immobility.

To examine differences in mobility for entrepreneurs, self-employed and employed, intergenerational asset persistence is estimated by applying least squares to the model (5). Dummy variables are added for the different groups of workers. Table 7 shows the results. For both generations, the correlation between parents' wealth and children's wealth is higher for the group of entrepreneurs and the self-employed

\section{Table 7. Intergenerational wealth persistence}

\begin{tabular}{|c|c|c|c|c|}
\hline \multirow[t]{2}{*}{ Variable } & \multicolumn{2}{|c|}{$\begin{array}{c}\text { Respondents born } \\
\text { between } 1942 \text { and } 1964 \\
(2,752 \text { obs. })\end{array}$} & \multicolumn{2}{|c|}{$\begin{array}{c}\text { Respondents born } \\
\text { between } 1965 \text { and } 1981 \\
(2,635 \text { obs. })\end{array}$} \\
\hline & Coeff. & Std. error & Coeff. & Std. error \\
\hline Parents' wealth index & $0.602^{* * *}$ & 0.027 & $0.676^{* * *}$ & 0.072 \\
\hline Age & $0.252^{* * *}$ & 0.092 & $0.158^{* * *}$ & 0.105 \\
\hline Age squared & $-0.002^{* *}$ & 0.001 & $-0.001^{* *}$ & 0.001 \\
\hline Dummy for entrepreneuers & $0.911^{* * *}$ & 0.134 & $0.933^{* * *}$ & 0.147 \\
\hline Dummy for employees & $0.332^{* * *}$ & 0.078 & $0.241^{* * *}$ & 0.079 \\
\hline $\begin{array}{l}\text { Interaction of entrepreneurs with } \\
\text { parents' wealth index }\end{array}$ & -0.05 & 0.049 & 0.044 & 0.055 \\
\hline $\begin{array}{l}\text { Interaction of employees with } \\
\text { parents' wealth index }\end{array}$ & $-0.091^{* * *}$ & 0.033 & $-0.086^{* * *}$ & 0.033 \\
\hline Intercept & $-7.252^{* * *}$ & 2.408 & $-3.993^{* * *}$ & 1.703 \\
\hline \multicolumn{5}{|c|}{$\begin{array}{l}\text { Source: Author's calculations based on data from The } 2006 \text { ESRU Survey on Social Mobility in Mexico } \\
\text { (EMOVI-2006). } \\
* * *=\mathrm{p}<0.01,{ }^{* *}=\mathrm{p}<0.05, *=\mathrm{p}<0.1\end{array}$} \\
\hline
\end{tabular}


than for employees. The persistence coefficient for the self-employed is 0.602 for the oldest generation and 0.672 for the youngest generation. Persistence is lower by 0.8-0.9 for employees. Therefore, self-employed workers have experienced lower relative wealth mobility than employees in both cohorts; i.e., the wealth of the self-employed is determined to a higher degree by their parents' wealth. The persistence coefficient for entrepreneurs is lower for the older cohort and higher for the youngest cohort when compared to the self-employed; however, they are not statistically significant. Thus, we cannot determine whether intergenerational relative wealth mobility for entrepreneurs has been higher or lower than that for the self-employed.

\section{CONCLUDING REMARKS}

Using data from the EMOVI-2006, which collects current and retrospective information on respondents and their parents, we analyze entrepreneurial activity in Mexico. Our study falls within the scope of intergenerational social mobility theory, i.e., the examination of socioeconomic changes experienced by individuals compared with their parents. In this retrospective context, the occupational characteristics of parents and their relative position in the socioeconomic spectrum are explored as possible determinants of the occupational choices of adult children. Then, entrepreneurs' intergenerational relative wealth mobility is measured and compared to that of employees and selfemployed workers.

Contrary to what is often considered in empirical studies of entrepreneurial activity in developed countries, we do not equate entrepreneurship with self-employment. Rather, we define entrepreneurs as business owners or partners who employ workers ( $8.3 \%$ of respondents), while the self-employed are own-account workers (30\% of respondents). We find that the characteristics of these two groups of workers differ in various ways, which supports our view that own-account workers do not necessarily perform the functions of entrepreneurs in the economy. Those functions include managing uncertainty in the market, innovating, taking risks, and coordinating factors of production.

Probit models are estimated to identify the determinants of the decision to become an entrepreneur. The independent variables include predetermined respondents' sociodemographic characteristics, parental socioeconomic class and fathers' occupation. Having a father who is an entrepreneur is the variable that increases the probability the most. The 
results suggest that in Mexico, the decision to become an entrepreneur is strongly determined by the father's occupation, and not necessarily by the individual's initial wealth or educational attainment.

Using the propensity score matching method, the mean effect of entrepreneurial activity on individual income is estimated. For the group of all entrepreneurs, entrepreneurship is found to increase income by 12 to $22 \%$. When the exercise is conducted by parental socioeconomic class, the effect observed for entrepreneurs with parents who belonged to the extreme quintiles is significantly higher than that observed for entrepreneurs with middle-class parents.

In order to analyze whether entrepreneurial activity is an effective vehicle for mobility, a wealth asset index is estimated for two birth cohorts - 1942-1964 and 1965-1981 - of respondents and their parents. The numbers in the intergenerational transition matrices for respondents and their parents' asset indices suggest that entrepreneurs are more likely to experience upward wealth mobility, but also that for entrepreneurs with lower-class parents it is more difficult to move to the top quintile. The econometric analysis indicates that self-employed workers experience lower relative wealth mobility than employees; i.e., the wealth of the self-employed is determined to a higher degree by their parents' wealth. However, whether entrepreneurs' relative mobility is higher or lower than that of the self-employed cannot be determined from this analysis.

The analysis has some limitations. The most important one is that it is not possible to identify all entrepreneurs who were engaged in entrepreneurial activities before the survey was conducted. Therefore, the results may be biased towards successful entrepreneurs. Second, more data on previous employment are needed to determine to what extent self-employment is the first step towards becoming a business owner who employs workers. Third, further analysis should be done to arrive at some policy implications. For example, it is important to investigate whether credit restrictions limit the increase in the number of successful entrepreneurs. 


\section{REFERENCES}

Altimir, O. (1987), "Income distribution statistics in Latin America and their reliability," Review of Income and Wealth 33(2): 111-55.

Behrman, J. R. and P. Taubman (1990), "The intergenerational correlation between children's adult earnings and their parents'income: Results from the Michigan panel survey of income dynamics," Review of Income and Wealth 36(2): 115-27.

Behrman, J. R., A. Gaviria and M. Székely (2001), "Intergenerational mobility in Latin America," Working Paper 452, Inter-American Development Bank.

Black, S. E. and P. J. Devereux (2010), "Recent developments in intergenerational mobility," IZA Discussion Paper Series No. 4866.

Censos Económicos (2009), "Resumen de los resultados de los Censos Económicos 2009," Instituto Nacional de Estadística y Geografía (INEGI), Mexico.

Corak, M. (2013), "Income inequality, equality of opportunity, and intergenerational mobility," Journal of Economic Perspectives, forthcoming.

Corak, M. and P. Piraino (2011), "The intergenerational transmission of employers," Journal of Labor Economics 29(1): 37-68.

Deininger, K. and L. Squire (1996), "New data measuring income inequality," The World Bank Economic Review 10(3): 565-91.

Dunn, T. and D. Holtz-Eakin (2000), "Financial capital, human capital, and the transition to self-employment: Evidence from intergenerational links," Journal of Labor Economics 18(2): 287-305.

Erikson, R. and J. H. Goldthorpe (1992), The constant flux: A study of class mobility in industrial societies. Oxford, England: Clarendon Press.

Filmer, D. and L. Pritchett (2001), "Estimating wealth effects without expenditure data - or tears: An application to educational enrollments in states of India," Demography 38(1): 115-32.

Glancey, K. S. and R. W. McQuaid (2000), Entrepreneurial economics. Great Britain: Palgrave MacMillan.

Heckman, J., H. Ichimura, J. Smith and P. Todd (1998a), "Characterizing selection bias using experimental data," Econometrica 66(5): 1017-98.

Heckman, J., H. Ichimura and P. Todd (1997), "Matching as an econometric evaluation estimator: Evidence from evaluating a job training programme," Review of Economic Studies 64(4): 605-54.

. (1998b), "Matching as an econometric evaluation estimator," Review of Economic Studies 65(2): 261-94.

Huerta, J. E. (2010), "El rol de la migración y las redes sociales en el bienestar económico y la movilidad social percibida," in Serrano, J. and F. Torche, eds., Movilidad social en México. Población, desarrollo y crecimiento. Centro de Estudios Espinosa Yglesias.

Hurst, E. and A. Lusardi (2004), "Liquidity constraints, household wealth, and Entrepreneurship," Journal of Political Economy 112(2): 319-47. 
Iversen, J., R. Jorgensen and N. Malchow-Moller (2008), "Defining and measuring entrepreneurship," Foundations and Trends in Entrepreneurship 4(1): 1-63.

Jantti, M., K. Roed, R. Naylor, A. Bjorklund, B. Bratsberg, O. Raum, E. Osterbacka, and T. Eriksson (2006), "American exceptionalism in a new light: A comparison of intergenerational mobility in the Nordic countries, the U.K. and the U.S." IZA Discussion Paper Series 1938.

Landstrom, H., G. Harirchi and F. Astrom (2012), "Entrepreneruship: Exploring the knowledge base," Elsevier Research Policy 41: 1154-81.

Lecuona Valenzuela, R. (2009), "El financiamiento a las pymes en México: La experiencia reciente," Economíaunam 6(17): 69-91.

Levy, S. (2008), Good intentions, bad outcomes: Social policy, informality, and economic growth in Mexico. Washington, D.C.: Brookings Institution Press.

Mazumder, B. (2005), "Fortunate sons: New estimates of intergenerational mobility in the United States using social security earnings data," The Review of Economics and Statistics 87(2): 235-55.

Naranjo, E., M. Campos, M. A. Flores and N. López (2012), "Monitor global de la actividad emprendedora. México 2012," Global Entrepreneurship Monitor (GEM).

Parker, S. C. (2004), The Economics of Self-Employment and Entrepreneurship. Cambridge: Cambridge University Press.

Quadrini, V. (1999), "The importance of entrepreneurship for wealth concentration and Mobility," Review of Income and Wealth 45(1): 1-19.

Rosenbaum, P. R. and D. B. Rubin (1983), "The central role of the propensity score in observational studies for causal effects," Biometrica 70(1): 41-55.

Sahn, D. E. and D. Stifel (2003), "Exploring alternative measures of welfare in the absence of expenditure data," Review of Income and Wealth 49(4): 463-89.

Sen, A. (1985), Commodities and Capabilities. Amsterdam: North-Holland.

. (1987), The Standard of Living. Cambridge: Cambridge University Press.

Serrano, J. and F. Torche, eds., (2010), Movilidad social en México. Población, desarrollo y crecimiento. Mexico, D.F.: Centro de Estudios Espinosa Yglesias.

Solon, G. R. (1992), "Intergenerational income mobility in the United States," American Economic Review 82: 393-408.

. (2002), "Cross-country differences in intergenerational earnings mobility," Journal of Economic Perspectives 16(3): 59-66.

. (2004), "A model of intergenerational mobility variation over time and place," in Corak, M. , ed., Generational income mobility in North America and Europe. Cambridge: Cambridge University Press.

Szekely, M. (2005), "Pobreza y desigualdad en México entre 1950 y el 2004," Secretaría de Desarrollo Social, Documentos de Investigación 24: 1-29.

Torche, F. (2009), "Sociological and economic approaches to the intergenerational transmission of inequality in Latin America," United Nations Development Programme, Regional Bureau for Latin America and the Caribbean Working Paper HD-09-2009. 
. (2010), "Cambio y persistencia de la movilidad intergeneracional en México," in Serrano, J. and F. Torche, eds., Movilidad social en México. Población, desarrollo y crecimiento. Mexico, D.F.: Centro de Estudios Espinosa Yglesias.

Torche, F. and S. Spilerman (2010), "Influencias intergeneracionales de la riqueza en México," in Serrano, J. and F. Torche, eds., Movilidad social en México. Población, desarrollo y crecimiento. Mexico, D.F.: Centro de Estudios Espinosa Yglesias.

UNDP (2010), Regional human development report for Latin America and the Caribbean 2010. Acting on the future: Breaking the intergenerational transmission of inequality. Costa Rica: Editorama.

Velez-Grajales, R., R. Campos-Vazquez, and C. E. Fonseca Godínez (2011), "El concepto de movilidad social: dimensiones, medidas y estudios en México," Working Paper, Centro de Estudios Espinosa Yglesias.

Wyrwich, Michael (2013), "In the name of my parents: Entrepreneurship and the intergenerational transmission of values," Jena Economic Research Papers, 2013-31. 